\title{
COMPROMISE SOLUTION TO THE CONFLICTING OBJECTIVES IN THE MANAGEMENT OF THE ARAFURA SEA SHRIMP FISHERY
}

\author{
Purwanto \\ Researcher at Research Center for Fisheries Management and Conservation, Ancol-Jakarta \\ Received November 26-2010; Received in revised form January 28-2011; Accepted February 7-2011
}

\begin{abstract}
Fisheries mis-management, including over allocation of fishing vessels, and illegal fishing practices in the Arafura Sea shrimp fishery had resulted in over exploitation of shrimp stock and economic losses. Improvement of fisheries management had decreased illegal fishing practices and permitted fishing effort to the level closer to the optimal economic level, resulting in the optimum profit. Unfortunately, the optimum profit was not the only objective, the management of fisheries in Indonesia has multiple conflicting objectives that could not be achieved simultaneously. The result of the analysis presented here shows that multiple objective programming technique can be used to determine a compromise solution to the conflicting objectives in the fisheries management.
\end{abstract}

\section{KEYWORDS: $\quad$ bio-economic, multiple objective programming, shrimp fishery}

\section{INTRODUCTION}

Arafura Sea is the most important fishing ground for shrimp fishery in Indonesia. The shallow waters of this fishing ground are highly productive (Bailey et al., 1987), as this area is regularly enriched by nutrient rich upwelling (Wyrtki, 1961) and nutrient inputs transported by water mass from the dense forest in the hinterland of Papua and from the dense mangrove area along the west coast of Papua (Sadhotomo et al., 2003). The stock size of shrimps in the Arafura Sea was estimated to be about $45 \%$ of the total size of shrimp stocks in Indonesia (Ministry of Marine Affairs and Fisheries of Indonesia, 2006). The trawlable area for shrimp fishing in the Arafura Sea was about $74,000 \mathrm{~km}^{2}$, with water depths ranging from 10-50 meters (Naamin, 1984; Sadhotomo et al., 2003).

The commercial fishing operation targeting shrimps in the Arafura Sea was started in the early 1970 s after the findings rich shrimp stocks and the introduction of the double rigged shrimp trawl in that fishing area during the late 1960 s, prompted by strong international demand for shrimp (Bailey et al., 1987). Trawl became one of the main fishing gears in Indonesia as it was the most productive fishing gear for demersal fisheries. The fishing capacity of trawl fleet in the Arafura Sea was continuously developed, causing substantial reduction in the abundance of demersal stocks in this area. Widodo et al. (2001) evaluated the development of demersal fishery, including shrimp fishery, in the Arafura Sea and concluded that the stocks of demersal fishes and shrimps in this area were over exploited. However, fishing companies have continuously expressed their interest to develop demersal fishing business in the
Arafura Sea. Private sectors argued that profit could still be generated in the Arafura demersal fishery even though the demersal fishery resources have been reported to be over exploited. The over exploitation of shrimp stock in the Arafura Sea has threatened sustainability of these resources and resulted in resource rent loss. This condition had been worsened by illegal fishing practices undertaken by Indonesians and foreigners (Purwanto, 2010).

The Arafura Sea shrimp stock is a renewable resource having capability to recover when it is harvested, as long as the fishing intensity does not exceed the resource carrying capacity (Naamin, 1984; Badrudin et al., 2002; Purwanto, 2010). Increasing fishing intensity to the level higher than the carrying capacity results in the lower production and the lower economic benefits. An appropriate management strategy is required to sustained fishery resources and to optimise economic benefit from the utilisation of these resources as stated in the Fisheries Act No.31 of 2004. Other consideration in managing fishery resources is the objective of fisheries development. Based on the current policies of the Government of Indonesia in marine fisheries, there are four main objectives of fisheries development, namely alleviation of poverty (pro poor), creation of job opportunity (pro job), promotion of economic growth (pro growth), sustaining natural resources, and environment (pro environment). Considering those objectives of fisheries management, therefore, the objectives of the Arafura Sea shrimp fishery management and development should be (1) to sustain fishery resources, (2) to optimise fishers' income, (3) to increase employment opportunities, and (4) to optimise fishery production for domestic consumption and for processing to promote economic growth. 
The Arafura Sea shrimp fishery should also be managed to sustain fishery resources while optimising fishers' incomes, employment opportunity, and fisheries' contribution to the national economy. Based on the result of the study in the Java sea fishery, Purwanto (2003) shows that the management strategy intended to optimise fishers' income (objective 2) would also ensure sustainability of fishery resources (objective 1). Meanwhile, increasing employment opportunities (objective 3 ), and maximising fishery production (objective 4), which also means increasing fish production to its maximum possible level, would not result in optimum fishers' income. Furthermore, maximising employment opportunities may threaten the sustainability of fishery resources. These objectives cannot be achieved simultaneously as there are conflicts between objectives 1 and 2 on one hand, and objectives 3 and 4 on the other. These can also be relevant to the Arafura Sea shrimp fishery. An appropriate strategy is required to achieve these conflicting objectives of fisheries management.

The first objective of this study, therefore, was to formulate a bio-economic model of the Arafura Sea shrimp fishery. This model then was used to evaluate the economic of this shrimp fishery, including the impact of illegal fishing practice, and to estimate optimum levels of fishery that would be used in the formulation of the fishery management strategy accommodating conflicting objectives.

\section{MATERIALS AND METHODS}

A bio-economic model was used here to describe the economic conditions of shrimp fishery relating to fishing effort (E). This model, as introduced by Gordon (1954) with the production model developed by Schaefer (1957), consists of the following equations:

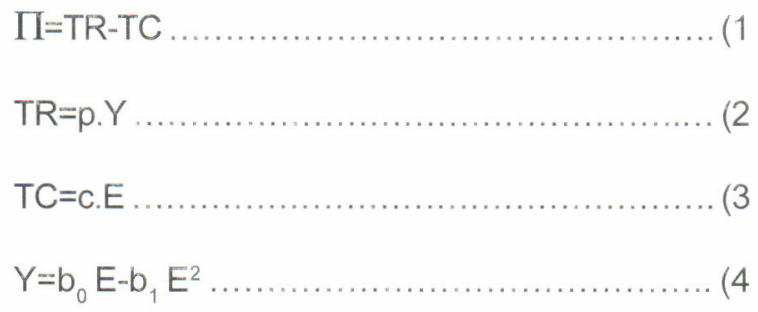

where:

$\Pi=$ profit gained in the shrimp fishery

$T R \quad=$ total revenue of fishing

$\mathrm{TC}=$ total cost of fishing

$\mathrm{Y}=$ annual production of shrimp fishery

$\mathrm{p}=$ average price of shrimps

C $=$ average cost of fishing per unit effort

$\mathrm{E}=$ fishing effort $\mathrm{b}_{0}$ and $\mathrm{b}_{1} \quad=$ coefficients of the production function

Equations (1)-(4) was used to evaluate the development of the shrimp fishery, with regard to gross revenue, cost, labor and profit, and the impact of illegal fishing practices on resource rent loss.

When the only objective of fisheries management was maximising profit, fishing effort was controlled at the level of production where optimum profit was gained, which was maximum economic yield. maximum economic yield and fishing effort to produce maximum economic yield $\left(E_{\mathrm{MEY}}\right)$ can be estimated by using the following equations:

$$
\begin{aligned}
& M E Y=a^{2} / 4 b-c^{2} /\left(4 b p^{2}\right) . \\
& E_{M E Y}=a / 2 b-c /(2 p b) \ldots .
\end{aligned}
$$

As there were conflicts between objectives in managing fisheries, namely between optimising fishers' income and sustaining fishery resources on one hand, and maximising employment opportunities and fishery production on the other, a multiple objective programming model was developed and used in this study with $E_{M E Y}$ and $E_{M S Y}$ as the lower limit and the upper limit reference points, respectively. The multiple objective programming model consisted of two objective functions, namely maximising fishers' income $\left[Z_{1}(x)\right]$ and maximising employment opportunity $\left[Z_{2}(x)\right]$, subjecting to a number of constraints. This model was mathematically represented as follows:

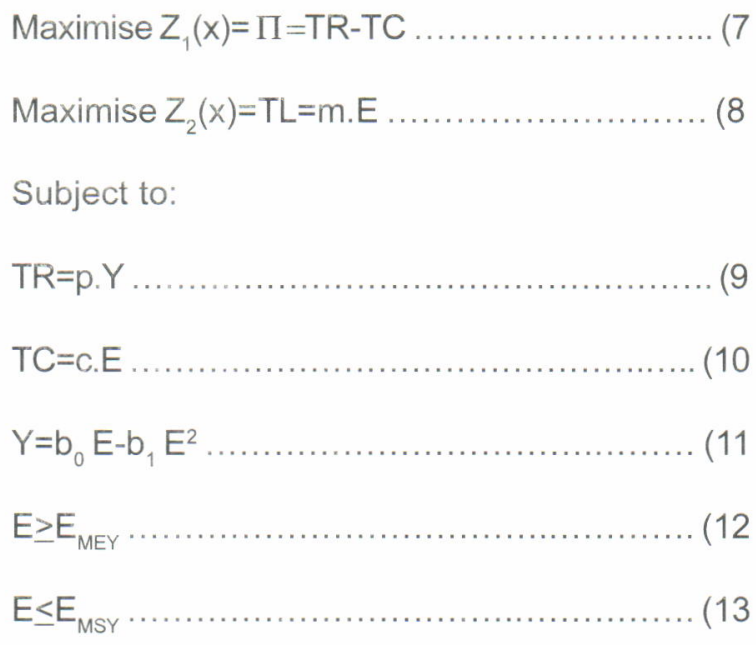

where:

$$
\begin{aligned}
& m=\text { average number of fishers working on a } \\
& \text { fishing vessel }
\end{aligned}
$$

This multiple objective policy analysis consisted of three steps, namely (1) estimating pay off matrix 
elements, (2) approximating a set of efficient solutions, and (3) determining the best compromise solution.

The elements of a pay off matrix were estimated by optimising each of the objectives separately and then computing the value of other objectives (Romero \& Rehman, 1989). The set of efficient solutions of the trade off between two objectives, that is efficient in the Paretian sense (Cohon, 1978; Romero \& Rehman, 1989), was then generated using the non inferior set estimation method (Cohon et al., 1979). Based on the Pareto principle, the solutions are efficient or optimal when a higher value of an objective can only be achieved by decreasing the value of another objective (Cohon, 1978; Balachandran \& Gero, 1984; Romero \& Rehman, 1989). The programming model for non inferior set estimation was formulated by Cohon (1978); Cohon et al. (1979) as follows:

Maximise $\left(Z_{2} U-Z_{2}\right) Z_{1}(x)+\left(Z_{1}-Z_{L 1}\right) Z_{2}(x) \ldots . .(14$ Subject to:

$x \in F$

where:

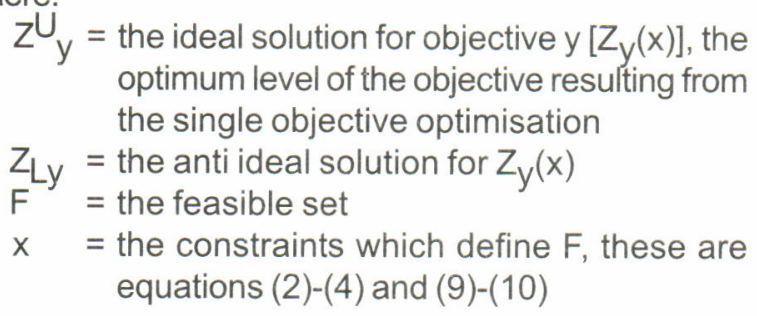

The best compromise solution, the solution that is closest to the ideal point, was determined by using compromise programming (Zeleny, 1973; Romero et al., 1987). To avoid biased results due to the differences in measurement units of the objectives, relative deviations were used (Zeleny, 1973). The following mathematical programming formulation was used to solve the best compromise solution (Romero et al., 1987):

Minimise $d_{0 O}$

Subject to:

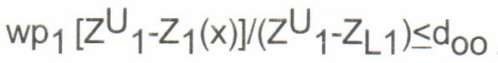

$$
\begin{aligned}
& w_{2}\left[Z^{U_{2}} Z_{2}(x)\right] /\left(Z^{U_{2}}-Z_{L 2}\right) \leq d_{o o}
\end{aligned}
$$

where:

$$
\begin{aligned}
\mathrm{d}_{\mathrm{OO}}= & \text { the relative deviation from an ideal solution } \\
w p_{y}= & \text { the weight attached to the importance of } \\
& Z_{y}(x) ; \text { the importance of the objectives are } \\
& \text { equal in this analysis, so } w p_{y}=1
\end{aligned}
$$

Those non linear programming problems were solved by using the GAMS/MINOS software (Brooke et al., 1992). Coefficients or parameters used for the programming in this study are presented in Table 1. Meanwhile the data on effort of the Arafura Sea shrimp fishery in 1996-2007 are from Purwanto (2008; 2010).

Table 1.

Coefficients or parameters used in the study

\begin{tabular}{ccll}
\hline Coefficients or parameters & Value & Unit & Source \\
\hline$p$ & 6.0 & US\$/kilogram & The Indonesian Shrimp \\
$c$ & 303,703 & US\$/vessel/year & Fishery Association \\
$m$ & 21 & People/vessel & \\
$b_{0}$ & 148.97 & & \\
$b_{1}$ & -0.121 & & Purwanto $(2008 ; 2010)$ \\
$E_{M E Y}$ & 406 & Vessels, standardised in & \\
$E_{M S Y}$ & 616 & shrimp trawl vessel & \\
\hline
\end{tabular}

\section{RESULTS AND DISCUSSION}

\section{Results}

\section{Development of the Fishery and its Optimum Level}

Estimated revenue increased with increasing fishing effort in early development of the fishery. After reaching the maximum revenue, further increase in the effort resulted in lower revenue. Meanwhile, the cost of fishing increased with increasing effort (Figure 1). Therefore, the same revenue from the Arafura Sea shrimp fishery may be produced with the lower fishing effort and lower cost, generating higher resource profit (Figure 1). 


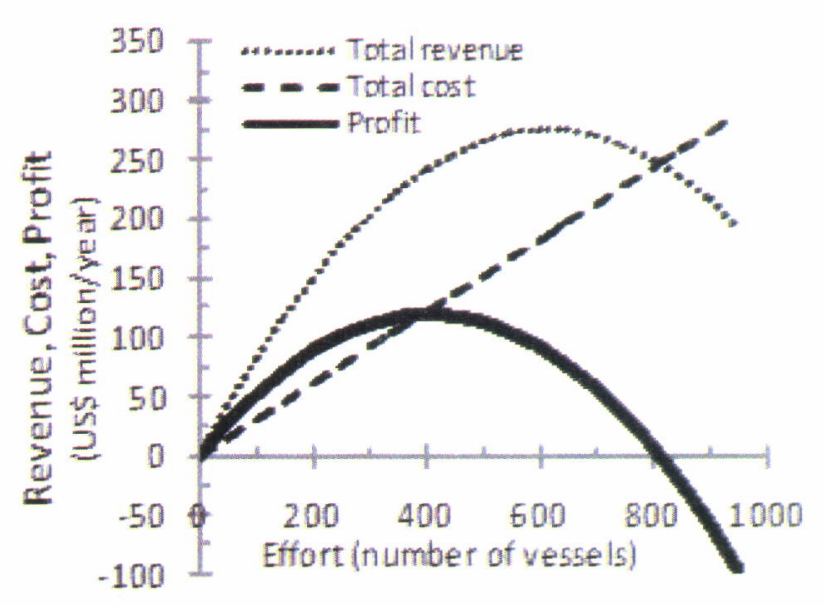

Figure 1.

The estimated total revenue, total cost, and profit generated in the Arafura Sea shrimp fishery at different level of fishing effort.

The estimated optimal profit that could be generated from the utilization of the shrimp stock in the Arafura Sea was about US\$119.8 million per year by operating 406 shrimp trawl vessels (Figure 1). The quantity of shrimps that could be harvested at this level of effort was 40,551 tonnes per year, which was maximum economic yield. This economically optimal level of fishing effort $\left(E_{M E Y}\right)$ was lower than the level of fishing effort resulting in the maximum sustainable yield and the maximum fishing revenue.

Meanwhile, the estimated profit per unit fishing vessel in the Arafura Sea shrimp fishery decreased with increasing fishing effort (Figure 2). On the contrary, increasing fishing effort increased the number of fishers in the Arafura Sea shrimp fishery.

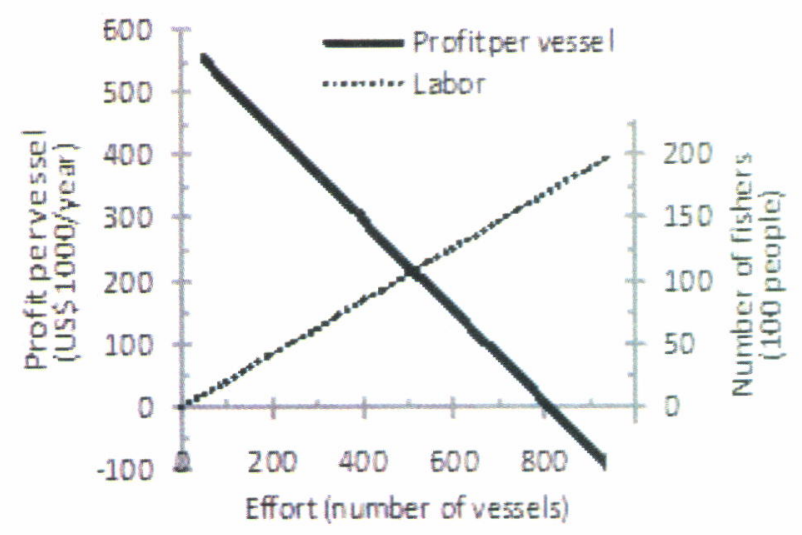

Figure 2. The estimated profit per unit vessel generated and the number of fishers in the Arafura Sea shrimp fishery at different level of fishing effort.
The actual effort during 1996-2007 exceeded the economically optimal effort $\left(E_{M E Y}\right)$, indicating that the shrimps stock in the Arafura Sea was economically over exploited during that period. Consequently, the profit of fishing was not optimum. Figure 3 shows that the worst conditions of the Arafura Sea shrimp fishery happened in year 2000. Fishing operation in the Arafura Sea by permitted vessels as well as illegal vessels was very substantial in 2000 . The shrimp stock was economically overfished in 2000 (Figure 3), resulting in very high resource rent loss.

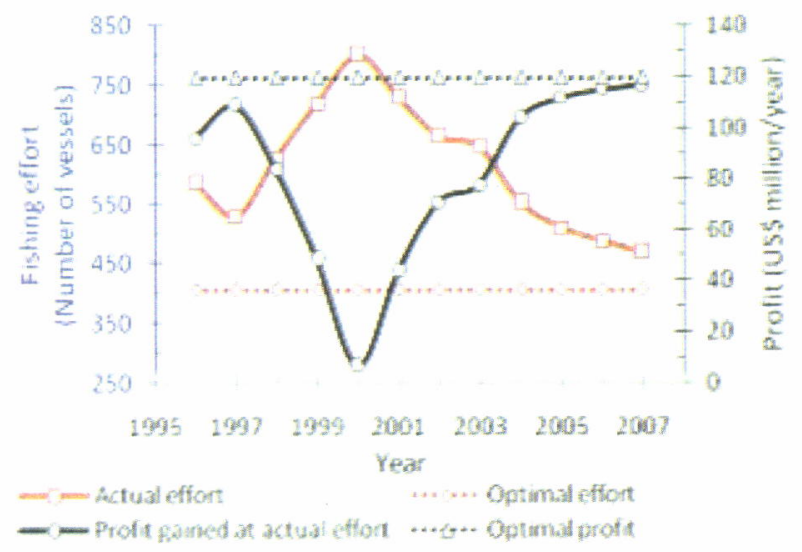

Figure 3. Fluctuations of fishing effort and profit, and the optimal levels of effort $\left(E_{\mathrm{MEY}}\right)$ and profit in the Arafura Sea shrimp fishery, 1996-2007.

The resource rent losses during 1996-2007 (Figure 4) was an impact of mismanagement and illegal fishing practices in the Arafura Sea shrimp fishery. The number of vessels received fishing licences to operate in the Arafura Sea was greater than the economically optimum number of fishing vessels. This over allocation of fishing licenses had resulted in the loss of resource rent. Higher rent loss resulted from higher over allocation. Similarly, higher rent loss resulted from higher intensity of illegal fishing practices. The fishing effort and the rent loss in 2000 were even the highest during 1996-2007, which were about 801 vessels and about $94 \%$ of the potential profit, respectively (Figure 3 and 4; Table 2). Since 2001 the Government of Indonesia had improved fisheries management, covering the development of licencing service capacity and quality, and the development of fisheries surveillance capacity and activity, including reregistration of fishing licence to ensure that the fishing holders are Indonesians and their vessels are Indonesian flag vessels. There were a number of fishing licences withdrawn as proper documents couldnot be submitted during re-registration period. Consequently, the fishing effort and the rent loss 
declined sharply after 2000 . Figure 4 indicates the decline tendency in the number of vessels received fishing licences and the intensity of illegal fishing practices.

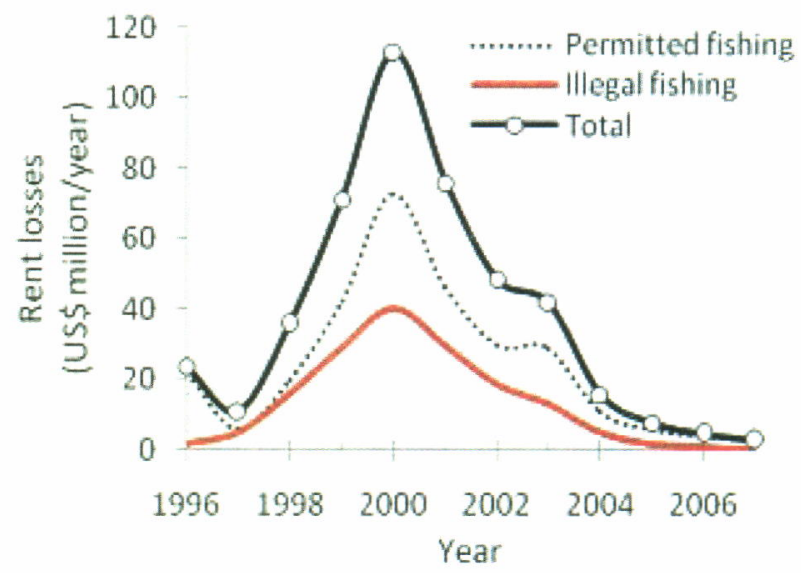

Figure 4.

Fluctuations of resource rent losses as an impact of illegal fishing and mis-management in the Arafura Sea shrimp fishery, 1996-2007.

\section{Conflicting Objectives and the Best Compromise Solution}

Table 2 shows that controlling fishing effort to the level that biologically optimum, that was 616 vessels, resulted in the maximum sustainable yield. At this effort level, the total revenue was also maximum. However, the profit was lower than the potential profit. At this biologically optimal fishing effort, the rent loss was about $27 \%$ of the potential profit. Meanwhile, controlling the fishing effort to the level that economically optimum, where the profit was at the maximum level, the shrimp production resulting was not at the maximum level. The number of fishers was lower than the number of fishers when the effort was controlled to the level that biologically optimum (Table 2 ). Therefore, the multiple objectives of fishery management, namely maximising shrimp production, maximising profit of fishery, maximising fisher income, and maximising job opportunity for fishers while ensuring sustainability of shrimp stock, could not be achieved simultaneously as those are conflicting objectives.

Table 2. Fishing effort, the number of fishers, estimated shrimp production, catch per unit of effort, total revenue, total cost, and profit generated in the Arafura Sea shrimp fishery in 2000, 2005, and their optimal levels

\begin{tabular}{llcccc}
\hline & \multicolumn{1}{c}{ Units } & Year 2000 & Year 2005 & $\begin{array}{c}\text { Biologically } \\
\text { optimum }\end{array}$ & $\begin{array}{c}\text { Economically } \\
\text { optimum }\end{array}$ \\
\hline Fishing effort & vessels & 801 & 509 & 616 & 406 \\
Number of fishers & people & 16.821 & 10.689 & 12.936 & 8,526 \\
Shrimp production & tonnes/year & 41,681 & 44.487 & 45,851 & 40.551 \\
Catch per unit effort & tonnes/vessel & 52.02 & 87.33 & 74.49 & 99.81 \\
Total revenue & US\$ million/year & 249.93 & 266.75 & 274.93 & 243.15 \\
Total cost & US\$ million/year & 243.33 & 154.70 & 186.95 & 123.39 \\
Total profit & US\$ million/year & 6.60 & 112.05 & 87.98 & 119.76 \\
Profit pervessels & US\$ 1000/year & 8 & 220 & 143 & 295 \\
\hline
\end{tabular}

When the strategy was optimising profit, fishers' income would increase, and shrimp stock would be sustainable. The strategy to optimise shrimp production, on the other hand, would optimise raw material for shrimp processing, and would increase livelihood opportunity for fishers. Figure 5 illustrates the trade off between the objectives of optimising economic profit of fishery and increasing employment opportunities constrained by $E_{M E Y}$ and $E_{M S Y}$ as the lower limit and the upper limit reference points, respectively. The compromise solution to this conditions resulted from the multi objective optimisation with those limit reference points.
The estimated levels of employment and total fishers' income at point A result from the strategy of income optimisation. On the other hand, point B represents the strategy of maximising employment opportunities constrained by $E_{M S Y}$ (Figure 5). Non feasibility of simultaneously achieving the optimum income and the optimum employment can be shown from the position of the co-ordinate of these ideal solutions, that is point $\mathrm{H}$ in Figure 5, which is outside of the frontier of the income employment trade off. The best compromise solution for the conflict between the two objectives is represented by point $\mathrm{K}$ in Figure 5 . 


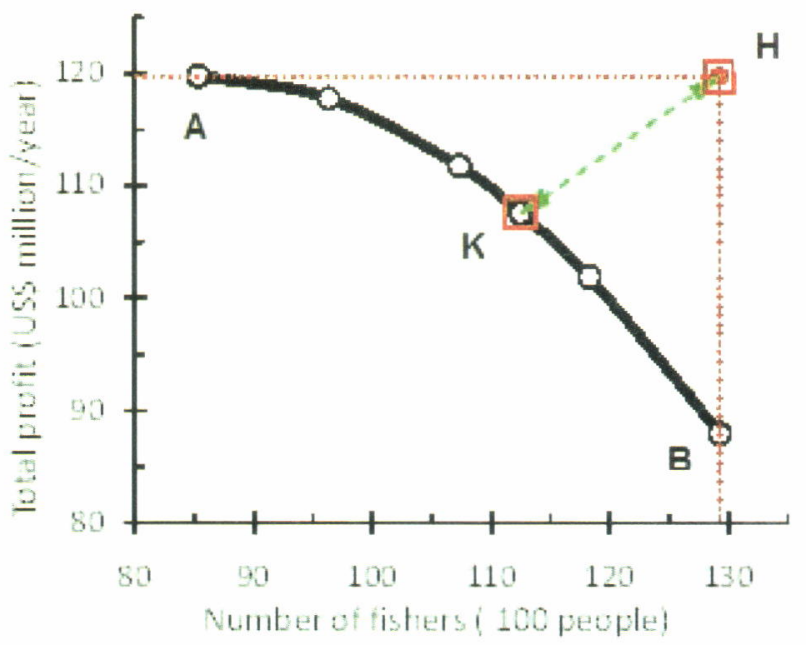

Figure 5. A trade off curve for the employment opportunity, measured by the number of fishers, and total income gained by fishers in the Arafura Sea shrimp fishery.
There are a number of consequences of achieving the best compromise solution as presented in Table 3. If the previous priority of the fisheries management and development was provided to increasing domestic fish consumption and maximising employment opportunities with $\mathrm{E}_{\mathrm{MSY}}$ as an upper limit of the fishing effort, the best compromise solution should be achieved by decreasing the number of vessels to 536 units. This strategy decreased the number of fishers but increased the profit. On the contrary, If the previous priority of the fisheries management and development was provided to increasing maximising profit of fishery with $E_{M E Y}$ as an lower limit of the fishing effort, the best compromise solution provided higher employment opportunities by increasing the number of vessels to 536 units, which decreased the profit that could be gained.

Table 3. Profits gained, number of fishers, number of fishing vessels, and shrimp production, vessel productivity, and profit per vessel at different reference points for the Arafura Sea shrimp fishery management

\begin{tabular}{|c|c|c|c|c|c|c|c|c|c|c|c|}
\hline \multirow[b]{2}{*}{$\begin{array}{l}\text { Efficient } \\
\text { points }\end{array}$} & \multirow[b]{2}{*}{ Reference points } & \multirow[b]{2}{*}{$\begin{array}{c}\begin{array}{c}\text { Number } \\
\text { of vessels } \\
\text { (unit) }\end{array}\end{array}$} & \multirow[b]{2}{*}{$\begin{array}{c}\text { Profit } \\
\text { (US } \$ 10^{6} / \text { year) }\end{array}$} & \multirow[b]{2}{*}{$\begin{array}{l}\text { Number of fishers } \\
\text { (people) }\end{array}$} & \multirow[b]{2}{*}{$\begin{array}{l}\text { Shrimp production } \\
\text { (tonnes/year) }\end{array}$} & \multirow[b]{2}{*}{$\begin{array}{l}\text { Vessel pro-ductivity } \\
\text { (tonnes/year) }\end{array}$} & \multirow[b]{2}{*}{$\begin{array}{l}\text { Profit per vessel } \\
\text { (US } \$ 10^{3} / \text { year) }\end{array}$} & \multicolumn{2}{|c|}{ Negative deviation } & \multicolumn{2}{|c|}{ Relative deviation } \\
\hline & & & & & & & & $\begin{array}{c}\text { Profit } \\
\text { (US } \$ 10^{6} / \text { year) }\end{array}$ & $\begin{array}{l}\text { Number } \\
\text { of fishers } \\
\text { (people) }\end{array}$ & $\begin{array}{l}\text { Profit } \\
(\%)\end{array}$ & $\begin{array}{c}\text { Number } \\
\text { of fishers } \\
(\%)\end{array}$ \\
\hline A & $E_{\text {MEY }}$ & 406 & 119.8 & 8,532 & 40,551 & 99.8 & 294.8 & 0 & 4,395 & 0 & 100 \\
\hline k & Compromise solution & 536 & 107.6 & 11,248 & 45,078 & 84.1 & 200.7 & 12.2 & 1,679 & 38 & 38 \\
\hline B & $E_{\text {MSY }}$ & 616 & 88.0 & 12,927 & 45,851 & 74.5 & 142.9 & 31.8 & 0 & 100 & 0 \\
\hline
\end{tabular}

The profit and their negative deviation at the best compromise solution were US\$107.6 million/year and US\$ 12.2 million/year, respectively (Table 3). Meanwhile, the number of fishers and their negative deviation at the best compromise solution were 11,248 people and 1,679 people, respectively (Table 3 ). At the best compromise solution, the degree of closeness of profit and labour to the ideal points were equal; the relative deviations from their ideal solutions were about $38 \%$.

To implement fisheries management and development policy with conflicting objectives, therefore, the best compromise solution should be adopted. The fishing effort should be controlled to the level of 536 vessels to achieve the best compromise solution for the Arafura Sea shrimp fishery.

\section{Discussion}

The result of the analysis presented previously shows that mis-management, including over allocation of fishing vessels, and illegal fishing practices in the Arafura Sea shrimp fishery had resulted in over exploitation of shrimp stock and economic losses.
Improvement in the Indonesian fisheries management policy, including improvement in the fishery licensing system and re-registration of vessels holding fishing licences, development of the fisheries surveillance and increasing law enforcement had been undertaken by the Government during 2001-2005. The improvement had resulted in the lower number of vessels holding fishing vessels, as fishing licences had been withdrawn from the vessels that could not submit proper documents during re-registration process, and the decline in the intensity of illegal fishing practices. Consequently, the number and the total tonnage of the shrimp and fish trawl vessels operated were decline during year 2001-2005. The fishing effort decreased from 801 vessels in 2000 to 509 vessels by 2005 , which was lower than the effort to produce maximum sustainable yield (Table 2). These resulted in positive impacts to the abundance of the shrimp stock, as indicated by the catch per unit effort (Cadima, 2003), and to the shrimp fishery, as indicated by higher productivity, higher profitability and lower rent loss (Table 2 and Figure 4). As the shrimp resource is a fast growing one, the shrimp stock in the Arafura Sea biologically recovered, and 
the rent loss was very small, about $6 \%$ of the potential profit, by 2005 . Clearly, the results of the improvement in fisheries management are remarkable.

Current fisheries management practices need to take into account the biotic, a-biotic, and human components of ecosystems in which fisheries operate. There is a recognition of the multiple objectives and values of fishery resources and marine ecosystems within the context of sustainable development. The concept of sustainable development requires an ecosystem approach to fisheries, which is a holistic approach that balances both human well being and ecological well being. The demand has increased to implement an ecosystem approach to fisheries that strives to balance diverse societal objectives (Food and Agriculture Organization, 2003). Management of fisheries is a complex task, as society has a number of objectives to achieve from the use of fishery resources. These include conservation, economic, and social objectives. However, these objectives often conflict, due to the varying opinions of the many stakeholders (Mardle \& Pascoe, 1999). The bioeconomic model of Arafura Sea shrimp fishery developed here reveals the effects of fisheries management to achieve different objectives, by implementing different reference points, on changes in bio-physical and economic conditions. The result of the analysis shows non feasibility of simultaneously achieving the multiple conflicting objectives of fishery management, namely maximising shrimp production, maximising profit of fishery, maximising fishers' income, and maximising job opportunity for fishers while ensuring sustainability of shrimp stock. Each one of these fishery management objectives should be achieve with different reference points. A similar case was reported by Purwanto (2003) in the Java Sea small pelagic fishery. The multiple objective programming model developed and applied here had demostrated the potential usefullness of multiple objective programming technique in determining a compromise solution to the conflicting objectives in the management and development of fisheries that can be used to provide justification and further information to the planning process.

\section{CONCLUSION}

1. On the basis of the result of the analysis shows, it can be concluded that fisheries mis-management, including over allocation of fishing vessels, and illegal fishing practices in the Arafura Sea shrimp fishery had resulted in over exploitation of shrimp stock and economic losses. Improvement of fisheries management that had been undertaken by the Government of Indonesia during 2001-2005 had decreased illegal fishing practices and permitted fishing effort closer to the optimal level that increased economic profit.

2. The objectives of management and development of fisheries in Indonesia were conflicting objectives. The result of the analysis also shows that multiple objective programming technique can be used to determine a compromise solution to the conflicting objectives in the fisheries management and development.

\section{REFERENCES}

Bailey, C., A. Dwiponggo, \& F. Marahudin. 1987. Indonesian Marine Capture Fisheries. ICLARM Studies and Reviews 10.

Brooke, A., D. Kendrick, \& A. Meeraeus. 1992. GAMS: A User's Guide, Release 2.25. The Scientific Press. South San Francisco.

Badrudin, B. Sumiono, \& N. Wirdaningsih. 2002. Laju tangkap, hasil tangkapan maksimum (maximum sustainable yield), dan upaya optimum perikanan udang di Laut Arafura. Jurnal Penelitian Perikanan Indonesia. 8(4): 23-29.

Cohon, J. L. 1978. Multiobjective Programming and Planning. Academic Press. New York. 333 pp.

Cohon, J. L., R. L. Church, \& D. P. Sheer. 1979. Generating Multiobjective Trade offs: An Algorithm for Bi-Criterion Problems. Water Resources Research. 15: 1,001-1,010.

Cadima, E. L. 2003. Fish stock assessment manual. Food and Agriculture Organization Fisheries Technical Paper. No. 393. Rome. Food and Agriculture Organization. 161 pp.

Food and Agriculture Organization. 2003. Fisheries management: 2. The Ecosystem Approach to Fisheries. Food and Agriculture Organization Technical Guidelines for Responsible Fisheries. No.4, Suppl. 2. Rome. Food and Agriculture Organization. 2003. 112 pp.

Gordon, H. S. 1954. The economic theory of the common property resource: The fishery. Journal of Political Economy. 62: 124-42.

Ministry of Marine Affairs and Fisheries. 2006. Marine and Fisheries Statistic 2005. 
Mardle, S. \& S. Pascoe. 1999. A Review of Applications of Multiple Criteria Decision Making Techniques to Fisheries. Marine Resource Economics. 14: 41-63

Naamin, N. 1984. Dinamika populasi udang jerbung (Penaeus merguiensis de Man) di perairan Arafura dan alternatif pengelolaannya [Population dynamics of banana shrimps (Penaeus merguiensis de Man) in the Arafura waters and its management alternatives]. Disertasi. Fakultas Pasca Sarjana. Institut Pertanian Bogor. 281 pp.

Purwanto. 2003. Status and management of the Java Sea fisheries. 793-832. In G. Silvestre, L. Garces, I. Stobutzki, M. Ahmed, R. A. Valmonte-Santos, C. Luna, L. Lachica-Aliño, P. Munro, V. Christensen, \& D. Pauly (eds.). Assessment, management, and future directions for coastal fisheries in Asian Countries. WorldFish Center Conference Proceeding. 67: 1,120 pp.

Purwanto. 2008. Resource rent generated in the Arafura Sea shrimp fishery. Final Draft. Prepared for the World Bank PROFISH Program. Washington. D. C

Purwanto. 2010. The biological optimal level of the Arafura Sea shrimp fishery. Indonesian Fisheries Research Journal. Research Center for Fisheries Management and Conservation. 16(2): 79-89.

Romero, C., F. Amador, \& A. Barco. 1987. Multiple objectives in agricultural planning: A compromise programming application. American Journal of Agricultural Economics. 69: 78-86.
Romero, C. \& T. Rehman. 1989. Multiple Criteria Analysis for Agricultural Decisions. Elsevier Science Publishers. Amsterdam. 257 pp.

Schaefer, M. B. 1957. Some considerations of population dynamics and economics in relation to the management of marine fisheries. Journal of the Fisheries Research Board of Canada. 14: 669-81.

Sadhotomo, B., P. Rahardjo, \& Wedjadmiko. 2003. Pengkajian kelimpahan dan distribusi sumber daya demersal dan udang di perairan Laut Arafura [An assessment of the abundance and distribution of demersal and shrimp stocks in the Arafura Sea]. Prosiding Forum Pengkajian Stok Ikan Laut 2003. Pusat Riset Perikanan Tangkap. Departemen Kelautan dan Perikanan. Jakarta.

Wyrtki, K. 1961. Physical oceanography of the Southeast Asian Waters. NAGA Report. 2: 195 pp.

Widodo, J., Purwanto, \& S. Nurhakim. 2001. Evaluasi Penangkapan Ikan di Perairan ZEEI Arafura: Pengkajian Sumber Daya Ikan Demersal [An Evaluation of Fishery in the IEEZ in Arafura: Assessment of Demersal Fishery Resources]. Direktorat Jenderal Perikanan. Departemen Kelautan dan Perikanan.Jakarta.

Zeleny, M. 1973. Compromise programming. 262-301. In J. L. Cochrane \& M. Zeleny (eds). Multiple Criteria Decision Making. Univ. South Carolina Press. Columbia. 